https://doi.org/10.18485/kud_kiaz.2019.ch1

\author{
Проф. др Александра Вранеш \\ aleksandra.vranes@gmail.com \\ Проф. др Љиљана Марковић \\ ljiljana.markovic@gmail.com \\ Универзитет у Београду \\ Филолошки факултет
}

\title{
О АЗЕРБЕЈЏАНУ, РЕЧ ПО РЕЧ ${ }^{1}$
}

Године 2018. на Филолошком факултету Универзитета у Београду основан је Центар Азербејџанског језика и културе, а на Азербејџанском универзитету језика, Центар српског језика и културе, са намером да се у њима и уз њихову подршку уче наша два језика и њима припадајуће књижевности и културе, као и да се одржавају различите културне манифестације, пројекти којима се потврђује поштовање националног идентитета и развија мултикултуралност, и организују научне конференције на интригантне и актуелне теме, које представљају научни изазов и неопходност. „Реч по реч“ током наших научних скупова и културних дешавања, установљено је да већ дуги низ, не само година, већ и деценија, Азербејџан у Србији није присутан као културна, већ више као политичка и социолошка константа.

О Азербејџану се код нас писало у ретким путописима, поводом књижевних превода, или када су праћена привредна и општа друштвена улагања.

Са намером да прикаже „културни напредак совјетских народа у њиховим источним републикама“, X. Муха-

1 Назив пројекта: Књиженство - теорија и историја женске књижевности на српском језику до 1915. год. Евиденциони број пројекта: 178029. 
ремовић о њима пише у кратким цртама, сажето али интригантно, и књигу насловљава Азербејчан, Узбекистан, Туркменија, Казахстан, Киргистан : биљешке о културном развитку источних народа СССР-а. Оцењујући стару народну књижевност поменутих народа као занимљиву и шаролику, он се нарочито посвећује савременој литератури, јер, по њему, она одражава дух народа који је тек у 20. веку „постао потпуни господар своје судбине, свога живота и своје земље“ (Мухаремовић: 16), који је „духовно препорођен, и морално чист, надахнут вјером и самопоуздањем у себе“ (Мухаремовић: 39). Мухаремовић од азербејџанских културних посленика истиче Самеда Боргума (Мухаремовић: 17); класика Абдулаха Шаика Талиба Задеа, учитеља многих младих писаца; Сулејмана Стаљског, „Хомера 20. вијека“ (Мухаремовић: 22); приповедача Отаџбинског рата Ризу Расулија; Самеда Вургуна и научника, преводиоца, драматурга Мирзу Ибрахимова; проф. М. Рафиљија; музичара и композитора Узеира Хаџибекова; кипара Пикоса Зорвоја.

А Десанка Максимовић, након боравка у „град(у) с десет центара“", како назива Баку, своја сећања почиње речима: „У Азербејџану сам некако стално мислила на дела Ива Андрића, на везире који дижу мостове, на старо турско господарство, на велике завојеваче, цара Мурата, старе велике песнике Истока, на нашу народну поезију. (...) И било ми је мило видети како (Азербејџанци - прим. аут.) сад живе спокојно у свом Баку на обали Каспијског језера, како дижу нове грађевине, нове градове.“ (Максимовић: 157) Десанка се диви отворености Азербејџана за светску књижевност, истовремено поштује и истиче Низамија, „великог песника 12. века“, и „Песника Физулија, славног и сад као некад у 16. веку“ (Максимовић: 159), песника 18. века Мола Панаха Вагифа и драмског писца који је о овом песнику писао Самеда Вургуна, „у 18. веку љубавне газеле Изедин Хасаногле“, сатиричног песника Мирзе Сабира, савременог књижевника с којим је Десанка посећивала по- 
зориште Џафира Сафарова, и песника са којима је дискутовала на састанку у савезу књижевника: Мирварида Диљбазија, Наби Бабајева, председника савеза Мехтија Хусеина.

На српском језику појавила се скоро књига која се детаљније бави историјом и културом Азербејџана. Књига Азербејиан од VII до IX века, аутора Зије Бунијатова, доктора историјских наука, објављена је 2016. године у преводу Градимира Полића и Нине Полић. Издавање књиге подржала је Амбасада Републике Азербејџан у Србији, жив и предан учесник свих пројеката и манифестација којима се азербејџанско културно наслеђе представља српској публици. Књига је резултат посвећених истраживања, нарочито археолошких и посебно нумизматичких материјала, како би се осветлила историја закавкаских народа. Она документовано говори о Азербејџану уочи арапских освајања, периоду под њиховом влашћу, формирању појединих самосталних држава и поседа на територији Азербејџана у другој половини IX века и покретима народних маса Азербејџана против калифата. Поуздани и коначни судови могу се доносити, објашњава у уводу књизи, и сам аутор, тек након што буду изучени сви средњовековни артефакти, којима се, према својим програмима, баве академије наука Грузије, Азербејџана и Јерменије, а за сада књигом аутор „идентификује кључне прекретнице историјског развојаи (...) најважније проблеме економске, политичке и социјалне историје земље“. (Бунијатов: 6)

Ово темељно научно дело осветљава и значај Азербејџана као блиставе цивилизације на Путу свиле. Тако, наглашава аутор : "Монете које су коване у Азербејџану често се срећу на налазиштима у северним земљама и у европском делу Русије. Локални трговци возили су своју робу у те земље, а трговци из тих земаља довозили робу у Азербејџан и Аран. У вези с тим, не можемо да искључимо постојање трговаца-посредника који су користили тај новац.” ( Бунијатов: 139 )

Књигом Знамените жене Азербејџана проф. др Зарифа Али Заде и проф. др Лала Маџидова објединиле су креа- 
тивност азербејџанских и српских ауторки. Представиле су речју и сликом, у духу тематских енглеских лексикона, на српском језику азербејџанске стваратељке, а на азербејџанском српске, циљано се обраћајући својој читалачкој публици. Из азербејџанског културног и историјског наслеђа узвисиле су се, по њиховом избору: суфијска поетеса Махсати Ганџави (12. век); дуговека предузетница, власница погона нафтне индустрије и мецена, Набат Ханум Ашурбекова (1795-1912); полиглота, слободоумна песникиња и успешна везиља Хуршидбану Натаван (1837-1897); оперска певачица, Народна уметница ССCР-а, оснивач прве позоришне високе школе и професор певања на Азербејџанском државном конзерваторијуму Шовкет Мамедова (1897-1981); „прва жена пилот на Истоку“ Лејла Мамедбекова 1909-1989); књижевница и преводилац из породице писаца Нигар Рафибејли (19131981); прва балерина, Народна уметница СССР-а ССР Азербејџана, главни кореограф Државног позоришта, опере и балета своје земље Гамар Алмасзаде (1915- 2006); специјалиста офталмологије и редовни професор, иридолог, редовни члан Азербејџанске академије наука Зарифа Алијева (1923-1985); прва жена композитор Шафига Ахундова (1924-2013); научница, оријенталиста, компаратиста Аида Имангулијева (1939-1992). Међу прослављеним Српкињама нашле су се: царица Милица; Оливера Лазаревић; Надежда Петровић; Милева Марић Ајнштајн; Исидора Секулић; Мага Магазиновић; Милунка Савић; Десанка Максимовић; Милена Павловић Барили и Радмила Бакочевић. Проф. др Зарифа Али Заде и проф. др Лала Маџидова2 подржале су иницијативу Амбасаде Азербејџана и амбасадора Елдара Хасанова3 да се развија

2 Проф. др ЛалQа Маџидова је и аутор књиге Путујем у Азербејџан, која кратком граматиком, одабраном лексиком и морфолошким и синтаксичким законитостима, уводи путника у језичке, географске и културолошке непознанице Азербејџана.

3 Др Елдар Хасанов, професор правних наука, објавио је током свога службовања у Београду 2015. године књигу Балкански мостови пријатељства, о географским, историјским, политичким, 
академска сарадња два народа. Проф. др Лала Маџидова била је и први руководилац Азербејџанског културног центра у коме је, током тог периода, реализовано више културних и научних програма, укључујући и конференцију о мултикултурализму.

Духовно наслеђе, етичко, естетско, филозофско, књижевно, уткано је у процесе модернизације уметности, самим тим и живота у Азербејџану. Ова књига представља тематски зборник научних радова истакнутих истраживача и културних посленика Азербејџана, у намери да се истакне значај међусобних изучавања српског и азерејџанског народа, али и да се читаоцима понуди актуелно штиво о основнм цивилизацијским и кутуролошким токовима у Азербејџану.

\section{Литература:}

ALI Zade, Zarife, 1958-

Znamenite žene Azerbejdžana / Zarife Ali Zade, Lala Madžidova. Beograd : Azerbejdžanski kulturni centar, 2016 (Beograd : Jovan). - 49, 53 str.

BAZINA, Mario

Kraljevi, kanovi, Sovjeti : (putopis) / Mario Bazina. - [1. izd.]. Zagreb : Mladost, 1989 (Zagreb : Mladost). - 275 str., [32] str. tabli. - (Biblioteka Prizma)

BUNIJATOV, Zija

Azerbejdžan od VII do IX veka : prevod sa ruskog jezika / Zija Bunijatov ; [prevod na srpki jezik Gradimir Polić, Nina Polić]. - Beograd : Total Trade International, 2015 (Beograd : Verzal). - 354 str.

HASANOV, Eldar

Balkanski mostovi prijateljstva / Eldar Hasanov ; [prevod Slavica Đukić]. - Beograd : Laguna, 2015 (Novi Sad : Artprint Media). - 308 str.

MAŽIDOVA, Lala

Putujem u Azerbejdžan / Lala Mažidova. - Beograd : Azerbejdžanski kulturni centar, 2012 (Loznica : Alfa). - 82 str. + [1] presvijen list karta Azerbejdžana

економским, демографским, конфесионалним, етнографским, културним координатама Западног Балкана. 
MUHAREMOVIĆ, $\mathrm{H}$.

Azerbejdžan, Uzbekistan, Turkmenija, Kazahstan, Kirgistan : bilješke o kulturnom razvitku istočnih naroda SSSR-a / H. Muharemović. - Sarajevo : [s.n.], 1946 (Sarajevo : Oslobođenje). - 40 str. Preštampano iz lista «Nova doba».

Prof. Aleksandra Vranes, $\mathrm{PhD}$

aleksandra.vranes@gmail.com

Prof. Ljiljana Markovic, PhD

ljiljana.markovic@gmail.com

University of Belgrade

Faculty of Philology

\section{ABOUT AZERBAIJAN WORD BY WORD ${ }^{4}$}

In 2018, the Center of Azerbaijani Language and Culture was established at the Faculty of Philology, University of Belgrade, but also at the Azerbaijani University of Language was established the Center of Serbian Language and Culture, with the intention that in them and with their support, learn our two languages and their corresponding literature and culture, as well as to maintain different cultural manifestations, projects that confirm the respect of national identity and develop multiculturalism and scientific conferences on intriguing and current topics that represent a scientific challenge and necessity. Word by word "during our scientific meetings and cultural events, it has been found that for many years, not only years, but for decades, Azerbaijan in Serbia has not been present as a cultural one, but rather as a political and sociological constant.

4 Project title: Knjizenstvo - theory and history of women's writing in Serbian language till 1915. Project registration number: 178029. 
About Azerbaijan was written in our rare journals, on the occasion of literary translations, or when economic and general social investments are monitored.

With the intention of showing "the cultural progress of the Soviet people in their Eastern republics", H. Muharemović writes about them briefly, summarily but intriguing, and calls the book Azerbaijan, Uzbekistan, Turkmenistan, Kazakhstan, Kyrgyzstan: notes on the cultural development of the eastern peoples of the USSR. Evaluating the old folk literature of the aforementioned peoples as interesting and varied, he especially devotes to modern literature, because, according to him, it reflects the spirit of the people who, in the twentieth century, "became the full master of their destiny, their lives and their lands" (Muharemović: 16), which is "spiritually rewarded, and morally pure, inspired by faith and self-confidence" (Muharemović: 39). Muharemović from the Azerbaijani cultural workers points out Samed Burgun (Muharemović: 17); the classics Abdullah Shaik Talib Zade, a teacher of many young writers; Sulejman Staljski, "Homer of the $20^{\text {th }}$ century" (Muharemović: 22); the narrator of the Fatherland War, Riz Rasul; Samed Vurgun and a scientist, translator, playwright Mirza Ibrahimov; prof. M. Rafili; musicians and composers Uzeyir Hajibeyov; sculptor Pikos Zorvoj.

Desanka Maksimović, after staying in the "city (s) with ten centers," as she calls Baku, begins with words: "In Azerbaijan, I was constantly thinking about the works of Ivo Andrić, on viziers that raise bridges, on the old Turkish lordship, on the great conquerors, Emperor Murat, on the old great poets of the East, on our national poetry. And I was very pleased to see that (Azerbaijanis - Author's Note) Now live quietly in their Baku on the shores of the Caspian lake, how they are raising new buildings, new cities. " (Maksimović: 157) Desanka admires the openness of Azerbaijan for world literature, at the same time respecting and emphasizing Nizami, "the great poet of the $12^{\text {th }}$ century" and "poet Fizuli, famous and now as it was once in the $16^{\text {th }}$ century" (Maksimović: 159), 
a poet of the 18th century, Molla Panah Vagif and a dramatic writer who wrote about this poet, Samed Burgun, "In the $18^{\text {th }}$ century love gazelles of Izedin Hasanoglu", the satirical poet Mirza Sabir, a contemporary writer with whom Desanka often visited the theater of Džafir Safarov, and poet with whom she discussed at a meeting in the Writers' Association: Mirvarid Diljbazi, Nabi Babayev, President of the Association, Mehdi Hussein.

In the Serbian language, there has appeared a book that deals more closely with the history and culture of Azerbaijan. The Book Azerbaijan from VII to the IX Century, by Zija Buniatov, doctor of Historical Sciences, was published in 2016 in the translation of Gradimir Polić and Nina Polić. The book was supported by the Embassy of the Republic of Azerbaijan in Serbia, a lively and committed participant in all projects and events that represent the Azerbaijani cultural heritage to the Serbian audience. The book is the result of dedicated research, especially archaeological and especially numismatic materials, in order to avenge the history of peoples of the Soviet Union. This book depicts Azerbaijan before the Arab conquest, the period under their authority, the formation of individual independent states and possession in the territory of Azerbaijan in the second half of the ninth century and the movements of the national masses of Azerbaijan against caliphate. The author in the introduction to the book explains that reliable and final courts can be made only after all the medieval artefacts are studied, which according to their programs are taught by the academies of science of Georgia, Azerbaijan and Armenia, , and for now the author according the book "identifies key milestones of historical development (...) the most important problems of the country's economic, political and social history." (Bunyatov: 6)

This comprehensive scientific work sheds light on the significance of Azerbaijani as a prospering civilization on the Silk Road. Thus, as the author emphasizes: "Coins that were made in Azerbaijani can be very often found on the 
archeological sites in northern countries and also in European part of Russia. Local merchants transported goods in those countries, and merchants from those countries brought good in Azerbaijani and Aran. Consequently, we cannot exlude the notion of merchants as intermediaries who used that money." (Bunijatov: 139)

According book Famous Women of Azerbaijan by the authors prof. Dr. Zarifa Ali-zade and prof. Dr. Lala Majidova the creativity of the Azerbaijani and Serbian authors was united. In the spirit of thematic English lexicon they presented by the word and the image, in the Serbian language, the Azerbaijani creators, and in the Azerbaijani, Serbian creators, specifically addressing to its readership audience. From the Azerbaijani cultural and historical heritage, according to their choice, are pointed out: Sufi poet Mahsati Ganjavi (12 ${ }^{\text {th }}$ century); a long-time entrepreneur, owner of the oil industry and patron saints, Nabat Hanum Ashurbekova (1795-1912); polyglot, a liberal poet and successful embroidered Hursidbanu Natavan (1837-1897); opera singer, folk artist of the USSR, founder of the first theater high school and professor of singing at the Azerbaijani State Conservatory, Shovkat Mammadova (18971981); "the first woman pilot in the East" Leyla Mamedbekova 1909-1989); writer and translator from the family of writers Nigar Rafibeyli (1913-1981); the first ballerina, the national artist of the USSR, the main choreographer of the State Theater, opera and ballet of his country, Gamar Almaszade (1915-2006); specialist in ophthalmology and full professor, iridologist, regular member of the Azerbaijani Academy of Sciences Zarifa Aliyeva (1923-1985); first female composer Shafiga Akhundova (1924-2013); scholar, orientalist Aida Imangulieva (1939-1992). Among the celebrated Serbs found themselves: Princess Milica Hrebeljanović; Olivera Lazarević; Nadežda Petrović; Mileva Marić Einstein; Isidora Sekulić; Maga Magazinović; Milunka Savić; Desanka Maksimović; Milena Pavlović Barili and Radmila Bakočević. Prof. Dr. 
Zarifa Ali-zade and prof. Dr Lala Majidova ${ }^{5}$ supported the initiative of the Embassy of Azerbaijan and Ambassador Eldar Hasanov ${ }^{6}$ to develop academic cooperation between the two nations. Prof. Dr. Lala Majidova was also the first head of the Azerbaijan Cultural Center in which during this period, several cultural and scientific programs, including a conference about multiculturalism, were realized.

Spiritual heritage, ethical, aesthetic, philosophical, literary, is embedded in the processes of modernization of art, and therefore life in Azerbaijan. This book is a thematic collection of scientific works of prominent researchers and cultural workers of Azerbaijan, in order to emphasize the importance of mutual study of the Serbian and Azerbaijani people, but also to offer readers the current study of basic civilizational and cultural trends in Azerbaijan.

\section{Literature:}

ALI Zade, Zarife, 1958-

Znamenite žene Azerbejdžana / Zarife Ali Zade, Lala Madžidova. Beograd : Azerbejdžanski kulturni centar, 2016 (Beograd : Jovan). - 49, 53 str.

BAZINA, Mario

Kraljevi, kanovi, Sovjeti : (putopis) / Mario Bazina. - [1. izd.]. Zagreb : Mladost, 1989 (Zagreb : Mladost). - 275 str., [32] str. tabli. - (Biblioteka Prizma)

BUNIJATOV, Zija

Azerbejdžan od VII do IX veka : prevod sa ruskog jezika / Zija Bunijatov; [prevod na srpki jezik Gradimir Polić, Nina Polić]. - Beograd : Total Trade International, 2015 (Beograd : Verzal). - 354 str.

5 Prof. Dr Lala Majidova is also the author of the book Travel to Azerbaijan, which by short grammar, selected lexical and morphological and syntactic laws, introduces passengers into linguistic, geographical and cultural unknowns of Azerbaijan.

6 During his service in Belgrade in 2015, Dr. Eldar Hasanov, professor of legal sciences, published the book Balkan Bridges of Friendship, about the geographical, historical, political, economic, demographic, confessional, ethnographic, cultural coordinates of the Western Balkans. 


\section{HASANOV, Eldar}

Balkanski mostovi prijateljstva / Eldar Hasanov ; [prevod Slavica Đukić]. - Beograd : Laguna, 2015 (Novi Sad : Artprint Media). - 308 str. MAŽIDOVA, Lala

Putujem uAzerbejdžan/Lala Mažidova. - Beograd: Azerbejdžanski kulturni centar, 2012 (Loznica : Alfa). - 82 str. + [1] presvijen list karta Azerbejdžana

MUHAREMOVIĆ, H.

Azerbejdžan, Uzbekistan, Turkmenija, Kazahstan, Kirgistan : bilješke o kulturnom razvitku istočnih naroda SSSR-a/H. Muharemović.

- Sarajevo : [s.n.], 1946 (Sarajevo : Oslobođenje). - 40 str.

Preštampano iz lista "Nova doba". 